\title{
The impacts of human activity on mammals in a community forest near the Dja Biosphere Reserve in Cameroon
}

\author{
Sophie Jane Tudge, Stephanie Brittain, Fabrice Kentatchime \\ Cédric Thibaut Kamogne Tagne and J. Marcus Rowcliffe
}

\begin{abstract}
Human activity in African tropical rainforests continues to threaten wild mammals. Many rural communities are dependent on hunting, yet there is a widespread lack of baseline data on ecology and the sustainability of hunting. We investigated the impacts of human activity on mammal species composition and distributions within a community forest surrounding a village in the buffer zone of the Dja Biosphere Reserve in south-east Cameroon. We conducted a camera-trap survey in August-November 2017 and detected 24 mammal species, including Critically Endangered western lowland gorilla Gorilla gorilla gorilla, Endangered central African chimpanzee Pan troglodytes troglodytes and Endangered tree pangolin Phataginus tricuspis. We used occupancy analysis to explore relationships between indicators of human activity (distance to a road and the Reserve), habitat quality (distance to the river and tree cover) and the distributions of species. We found that the local distribution of threatened mammals was not apparently limited by human activity, and proximity to the road did not negatively influence occupancy for any species. However, most of the Reserve's large species were not detected, including the African forest elephant Loxodonta cyclotis and the largest ungulates, and the occupancy of two species commonly hunted for wild meat was positively correlated with distance from the village, indicating hunting may be unsustainable. Our results show that the community forest provides habitat for threatened species outside the Reserve and in close proximity to people. However, effective conservation management will require continued monitoring and research to determine whether current rates of hunting are sustainable.
\end{abstract}

SOPHIE JANE TUDGE (Corresponding author, (1) orcid.org/0000-0002-0447-9448, sophietudge1@hotmail.com) Department of Life Science, Imperial College London, Silwood Park, Buckhurst Road, Ascot, SL5 7PY, UK

StePHANIE BRITTAIN (10 orcid.org/0000-0002-7865-0391) Department of Zoology, University of Oxford, Oxford, UK

Fabrice Kentatchime Central African Biodiversity Alliance, Yaoundé, Cameroon

Cédric Thibaut Kamogne Tagne Higher Institute of Environmental SciencesInternational Bilingual Academy of Yaoundé Sup, Yaoundé, Cameroon

J. MARCus RowclifFe (10 orcid.org/0000-0002-4286-6887) Institute of Zoology, Zoological Society of London, London, UK

Received 29 October 2020. Revision requested 28 January 2021.

Accepted 26 May 2021. First published online 3 February 2022.
Keywords Camera trapping, community forest, conservation, human activity, hunting sustainability, mammals, occupancy analysis, tropical rainforest

Supplementary material for this article is available at doi.org/10.1017/So030605321000806

\section{Introduction}

Wild mammals are facing an uncertain future as a result of human activity, with c. $20 \%$ threatened with extinction (Hoffmann et al., 2011). Tropical rainforests are species-rich, globally important ecosystems, but overexploitation and habitat loss pose major threats to their biodiversity (Butchart et al., 2010; Rosa et al., 2016). With the continued rise in the human population and consequent demand for forest products, rainforest species are likely to face increasing pressure (Fa et al., 2003; United Nations, 2019). Consequently, we must ensure their adequate conservation, both within and outside protected areas.

Central Africa contains the second largest area of tropical rainforest (Potapov et al., 2012), home to a unique range of biodiversity. In rural communities, subsistence hunting of rainforest mammals for food and commercial hunting for livelihoods remain important (Nasi et al., 2011; Ziegler et al., 2016). Additionally, some of the most threatened mammals have high economic value and are subject to hunting for illegal trade (Wasser et al., 2015; Ingram et al., 2018). The scale of commercial hunting in forests has increased for several reasons, including increased urban demand for wild meat (bushmeat), human population density and access via roads (e.g. Robinson \& Bennett, 2004; Ziegler et al., 2016; Fa et al., 2019).

Overharvesting of mammals is of concern as it leads to depletion and to changes in forest structure and ecosystem functioning, such as reduced seedling establishment and tree regeneration (Wang et al., 2007; Rosin \& Poulsen, 2016). In turn, a reduction in available protein can result in human malnutrition and food insecurity (Nasi et al., 2011). Despite challenges in measuring the sustainability of offtake, simple sustainability indicators can be useful (Milner-Gulland \& Rowcliffe, 2007). For example, hunter selectivity and intrinsic demography make larger species more vulnerable to overharvesting (Peres, 2000; Cowlishaw 
et al., 2005); a prey community dominated by ecologically versatile, smaller mammals typically reflects such overharvesting. This pattern of species depletion is often observed close to human settlements, reflecting spatial patterns of human population density and hunting effort (e.g. Koerner et al., 2017; Beirne et al., 2019). Therefore, species composition can be a useful indicator of hunting sustainability (MilnerGulland \& Rowcliffe, 2007).

Distance to roads can also be used as an indicator of human activity and, in some cases, hunting pressure. In Central Africa, expansion of industrial logging has resulted in an increased number of roads to transport goods and workers (Laporte et al., 2007). Roads allow hunters to exploit previously inaccessible forest areas and many studies have linked proximity to roads to increased hunting and negative impacts on mammals (e.g. Vanthomme et al., 2013; Ziegler et al., 2016). However, roads can also affect species behaviour and abundance, resulting in positive or negative associations that are species and location dependent and therefore hard to predict (e.g. Laurance et al., 2006; Vanthomme et al., 2013).

In Cameroon, community forests were made possible with the adoption of the Forestry Law in 1994, with the aims of reducing poverty in forest communities and protecting the environment (Egbe, 2001; Oyono et al., 2006). Within them, local people can manage forest resources subject to a simple management plan that is agreed between a community-level council and the government (Egbe, 2001; Lescuyer, 2013). Community forests occur along roads or around villages, can be up to 5,000 ha and are granted for a period of 25 years. Although most are focused on timber extraction, villagers can maintain agricultural activities and hunting of unprotected species, for subsistence only, within community forests. However, the extent to which the biodiversity conservation and socio-economic goals of community forests are met varies. Most studies have found few, if any, benefits to the community (e.g. Ezzine-de-Blas et al., 2009; Lescuyer, 2013), with progress hindered, inter alia, by management conflicts and a lack of technical skills (e.g. Ezzine-de-Blas et al., 2009; Alemagi, 2011). Inadequate monitoring and evaluation can allow environmental degradation to continue unchecked, and little research has been conducted on animal biodiversity within community forests (Lhoest et al., 2020), hindering examination of the sustainability of hunting.

Our research focuses on mammals within a community forest that surrounds a village on the southern periphery of the Dja Biosphere Reserve in Cameroon. This $5,260 \mathrm{~km}^{2}$ Reserve is a UNESCO World Heritage Site that supports c. 109 mammal species, including the African forest elephant Loxodonta cyclotis, western lowland gorilla Gorilla gorilla gorilla and central African chimpanzee Pan troglodytes troglodytes (Kingdon, 2015; Bruce et al., 2018a). However, a recent analysis suggests that the conservation success of this Reserve is low (Gruber et al., 2018), partly because of an increasing human population around the Reserve, where there are hundreds of small villages and a network of production forests, mining concessions and community forests. There are limited baseline data on the status of mammals in the Dja region, but recent surveys have provided information on the mammal community of the Reserve (Bruce et al., 2018a,c) and in three neighbouring community forests to the north-east (Lhoest et al., 2020). We conducted a camera-trap survey within a previously unsurveyed community forest to the south-east of the Reserve to provide baseline data on mammal species richness and composition. We used occupancy analysis to estimate the proportion of the survey area used by each species and to investigate how indicators of human activity influenced the distribution of species. We then used species composition and the relationship between human activity covariates and species occupancy to look for signs of overexploitation. Our findings could form the basis of wildlife monitoring within the study area and inform conservation management of wildlife within the community forest and wider Dja region.

\section{Study area}

The Dja region has a humid, equatorial climate and is characterized by semi-deciduous, lowland rainforest with a mean annual temperature of $23{ }^{\circ} \mathrm{C}$ and annual rainfall of $1,600 \mathrm{~mm}$ (Lagarde, 2004). Our study area is a village within a community forest in dense rainforest between the Dja Biosphere Reserve and the Dja River, c. $4 \mathrm{~km}$ south-east of the Reserve (Fig. 1). It comprises 90 households that rely heavily on forest resources for subsistence. The mean human population density is 5 people $/ 1 \mathrm{~km}^{2}$ (Center for International Earth Science Information Network, 2018) and villagers have mixed livelihoods, primarily agricultural, but many also fish, hunt and collect non-timber forest products. The village became a community forest in 2010 with the objectives of helping the community generate income and sustainably improve their living conditions. No previous research has examined hunting within the community forest, but during a scoping trip, villagers reported to us that it was relatively easy to find food by hunting and gathering. A permanent hunting camp was encountered during the survey, which is an area where residents of the village stay for a few nights when hunting or gathering further afield. Some small-scale logging took place within the community forest in 2011-2013 but there was no logging at the time of our survey. The village is relatively isolated and far from the nearest main road, although a logging road was built through the village in 2015, which during our survey carried c. 15-20 trucks per day to nearby logging concessions. The community forest has been bordered by a logging concession to the south since 2013 and there are numerous others in the vicinity. 


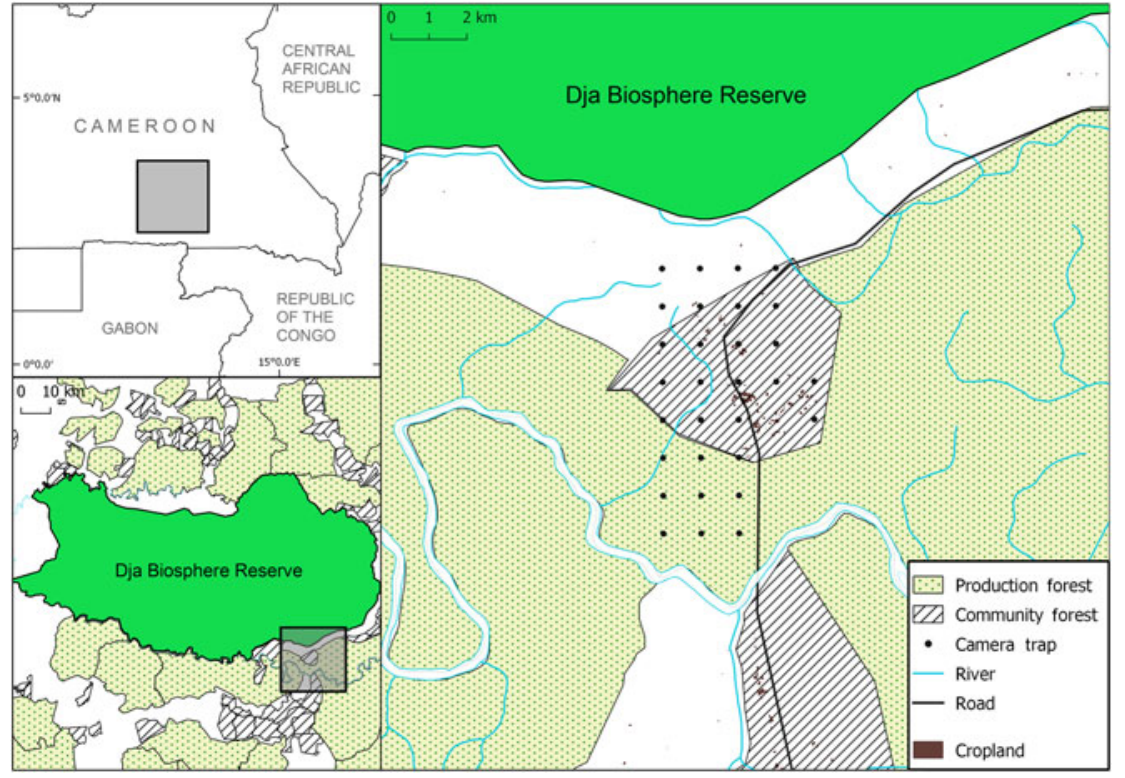

FIG. 1 Location of the study area and camera-trap grid, in place during AugustNovember 2017, across the community forest and adjacent production forest in the buffer zone of the Dja Biosphere Reserve, Cameroon.

\section{Methods}

\section{Survey design}

We placed a systematic grid of 30 camera traps (Bushnell, Overland Park, USA) set $1 \mathrm{~km}$ apart across the village, surrounding community forest and adjacent production forest. There was no logging within the surveyed area of production forest and, as it provided a continuation of the habitat found within the community forest, we did not consider it as a separate habitat in this study. Cameras were unbaited and operational continuously during August-November 2017. They took three photographs each time they were triggered, using low glow infrared flash set to medium, with a trigger speed of $0.14 \mathrm{~s}$ and a 1-s delay between triggers. Suitable places to position the cameras were chosen within $100 \mathrm{~m}$ of each grid point, close to frequently used animal trails (Amin et al., 2015) or possible feeding spots. Cameras were attached to trees c. $4 \mathrm{~m}$ from the trails. The cameras had high sensitivity and were placed $30-45 \mathrm{~cm}$ off the ground, angled horizontally. To avoid sunlight interfering with the cameras, they were set facing north or south (Bruce et al., 2018a). Tall grass and foliage that could have obstructed the field of view were cleared. The placement of two cameras close to the road had to be adjusted as they would have been within a hunting camp, but the 1 $\mathrm{km}$ spacing was not substantially compromised. The total survey area was c. $26 \mathrm{~km}^{2}$.

\section{Species richness and composition}

Species identification was aided by Kingdon (2015). For Herpestidae (mongoose) species, data were pooled because of the low numbers of records of individual species and difficulties of identification. We excluded images of small rodents that could not be identified to species level as their small body size limited detectability, resulting in sampling error (Tobler et al., 2008; Bruce et al., 2018a). We generated a species accumulation curve using the package vegan in $R$ 3.6.2 (Oksanen et al., 2019; R Core team, 2019) to examine whether our sampling effort was sufficient to capture the majority of mammal species and to estimate mammal species richness. To infer whether hunting was sustainable or not, species composition was compared with the terrestrial mammal community that would be expected within our study area with minimal human disturbance. The expected community was based on species whose distributions coincided with our study area according to Kingdon (2015) and the IUCN Red List (IUCN, 2021), were likely to be detected by ground-level camera traps within continuous forest in this area based on species ecology and habitat preferences, and were detected by camera-trap surveys in similar habitat within the Reserve (Bruce et al., 2018a,c) or in community forests to the north-east (Lhoest et al., 2020).

\section{Occupancy analysis}

We used occupancy analysis as it can be used to model species distributions while accounting for imperfect detectability (MacKenzie et al., 2002, 2006), and is being increasingly used as a monitoring tool (e.g. Ahumada et al., 2011; Rich et al., 2017). Species detection histories were created by recording the presence (1) or absence (o) of a species within 5-day windows at each camera trap, a compromise between having an adequate number of repeat visits and model stability. Single-species, single-season occupancy models were run using the package unmarked in $R$ (MacKenzie et al., 2002; Fiske \& Chandler, 2011). As the home ranges of the 
larger species in our study area are typically $>_{1} \mathrm{~km}^{2}$, we interpreted occupancy as the proportion of sites used by a species (MacKenzie et al., 2006; Da Silva et al., 2018).

We used the geoprocessing tools in QGIS 3.0.2 (QGIS Development Team, 2018) to derive indicators of human activity and habitat quality hypothesized to influence occupancy $(\psi)$ and/or detection probability ( $p$, the probability that a species is detected given that it occupies a site). For each camera location, we calculated proximity to the Dja Biosphere Reserve, proximity to the road, village, river and nearest production forest, altitude, human population density (Center for International Earth Science Information Network, 2018), slope and per cent of tree cover within a $200 \mathrm{~m}$ buffer (where land that was not forest was cropland) based on a land-cover map of Africa (ESA CCI Land Cover Team, 2017). Pearson correlation coefficients $(r)$ were used to test for correlation between pairs of covariates; if $r$ was $>0.7$ we excluded one of the pair and kept the covariate that most closely aligned with the aims of our study and our knowledge of the study area (Murphy et al., 2017). The final covariates included in our occupancy models were proximity to the road, Reserve and river, tree cover and slope (Supplementary Table 1). Slope was only used to model detection probability and the river to model occupancy, and the other covariates were used for both. Human population density and distance to the Reserve were highly correlated $(r=0.9)$. Covariates were standardized before modelling (Reilly et al., 2017).

We followed a systematic model selection approach, in which all combinations of covariates were modelled, following Murphy et al. (2017). Model selection was based on the second-order Akaike information criterion (AICc), including adjustment for overdispersion if the dispersion parameter $\hat{c}$ was $>1$ (QAICc; Burnham \& Anderson, 2002; MacKenzie \& Bailey, 2004). We excluded models that did not converge or produced estimates of $p<0.15$ and $\psi=1$ (MacKenzie et al., 2002). The top-ranked models were those with $\Delta(\mathrm{Q}) \mathrm{AICc}<2$ (MacKenzie et al., 2006). Where there was more than one top-ranked model, we conducted model-averaging with the AICcmodavg package in $R$ (Burnham \& Anderson, 2002; Mazerolle, 2017). The weight of evidence for each covariate was calculated by summing the AIC weights across candidate models containing that covariate (Burnham \& Anderson, 2002; Santos et al., 2016).

\section{Results}

\section{Species richness and composition}

Three memory cards malfunctioned in the field and did not provide any data, and another camera only worked for 1 day and therefore was excluded. The remaining 26 cameras took

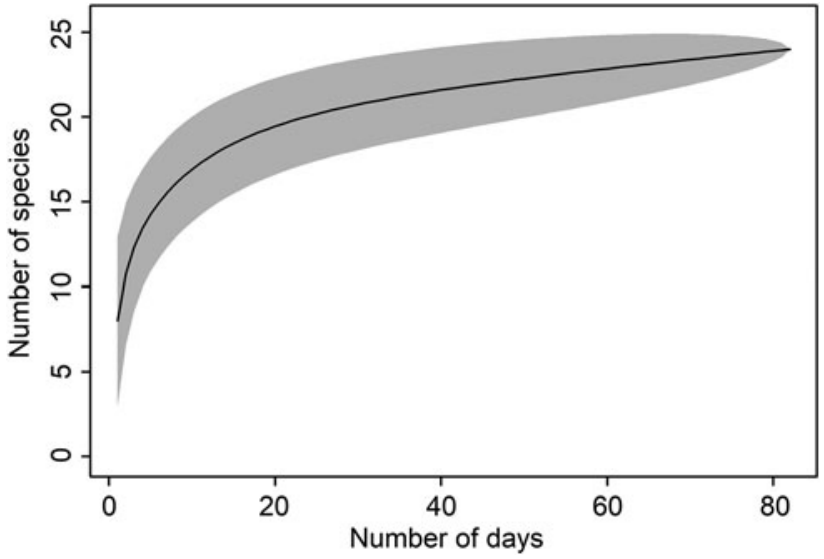

FIG. 2 Species accumulation curve for mammals identified by camera trapping during August-November 2017 in the community forest and surrounding habitat close to the Dja Biosphere Reserve, Cameroon (Fig. 1). The shaded ribbon indicates the $95 \%$ confidence interval.

16,050 photographs over 1,730 trap-days. The mammal species accumulation curve nearly reached a plateau, indicating that we detected most of the mammals within our survey area, except perhaps the most elusive or rare species, such as the leopard Panthera pardus (Bruce et al., 2018c; Fig. 2). Thirty-one species were detected: six birds, one monitor lizard and 24 mammals, including six mammals of conservation concern (Near Threatened bay duiker Cephalophus dorsalis, yellow-backed duiker Cephalophus silvicultor and putty-nosed monkey Cercopithecus nictitans, Endangered tree pangolin Phataginus tricuspis and chimpanzee, and Critically Endangered western lowland gorilla) and one galago that could not be identified to species. We identified four large mammals $(>25 \mathrm{~kg}), 16$ medium-sized mammals $(1-25 \mathrm{~kg})$ and three small mammals $\left(<_{1} \mathrm{~kg}\right)$ to species. We did not include birds or reptiles in our occupancy analyses as they were not the targets of our survey.

Gorillas were recorded rarely (eight photographs), resulting in insufficient data for occupancy analysis. Putty-nosed monkey and moustached guenon Cercopithecus cephus were also recorded rarely, but as these primates are arboreal, occupancy analysis based on detections of these species from ground-level camera traps would not have been appropriate. The species recorded the most were blue duiker Philantomba monticola, Peter's duiker Cephalophus callipygus, agile mangabey Cercocebus agilis and brush-tailed porcupine Atherurus africanus (Table 1). We did not detect Critically Endangered forest elephants, large felids, Endangered giant ground pangolin Smutsia gigantea or the largest ungulates predicted to occur in the area (Supplementary Table 2). Thirty per cent of the medium-sized and large species we detected were listed in the IUCN Red List as Near Threatened or in one of the threatened categories, as were $50 \%$ (eight species) of those that we did not detect. 
TABLE 1 Mammal species identified by camera trapping in the community forest and adjacent habitat surrounding the study village in the buffer zone of the Dja Biosphere Reserve in Cameroon (Fig. 1), with their Red List status (IUCN, 2021), trophic guild, body size, and naïve occupancy (the latter calculated as the number of cameras where the species was found divided by the total number of cameras).

\begin{tabular}{|c|c|c|c|c|}
\hline Species & Red List status ${ }^{1}$ & Trophic guild & Body size ${ }^{2}$ & Naïve occupancy \\
\hline \multicolumn{5}{|l|}{ Carnivores } \\
\hline African palm civet Nandinia binotata & LC & Omnivore & Medium & 0.31 \\
\hline Servaline genet Genetta servalina & LC & Omnivore & Medium & 0.31 \\
\hline Black-legged mongoose Bdeogale nigripes & $\mathrm{LC}$ & Carnivore & Medium & 0.04 \\
\hline Long-snouted mongoose Herpestes naso & LC & Carnivore & Medium & 0.15 \\
\hline Marsh mongoose Atilax paludinosus & $\mathrm{LC}$ & Carnivore & Medium & 0.12 \\
\hline Flat-headed cusimanse Crossarchus platycephalus & LC & Carnivore & Medium & 0.23 \\
\hline \multicolumn{5}{|l|}{ Pangolins } \\
\hline Tree pangolin Phataginus tricuspis & EN & Insectivore & Medium & 0.15 \\
\hline \multicolumn{5}{|l|}{ Ungulates } \\
\hline Blue duiker Philantomba monticola & LC & Herbivore & Medium & 0.85 \\
\hline Bay duiker Cephalophus dorsalis & NT & Herbivore & Medium & 0.50 \\
\hline Yellow-backed duiker Cephalophus silvicultor & NT & Herbivore & Large & 0.23 \\
\hline Peter's duiker Cephalophus callipygus & LC & Herbivore & Medium & 0.77 \\
\hline Bates' pygmy antelope Neotragus batesi & LC & Herbivore & Medium & 0.15 \\
\hline Red river hog Potamochoerus porcus & LC & Omnivore & Large & 0.42 \\
\hline \multicolumn{5}{|l|}{ Primates } \\
\hline Gorilla Gorilla gorilla gorilla & CR & Herbivore & Large & 0.04 \\
\hline Chimpanzee Pan troglodytes troglodytes & EN & Omnivore & Large & 0.31 \\
\hline Putty-nosed monkey Cercopithecus nictitans & NT & Omnivore & Medium & 0.04 \\
\hline Moustached guenon Cercopithecus cephus & LC & Omnivore & Medium & 0.04 \\
\hline Agile mangabey Cercocebus agilis & LC & Herbivore & Medium & 0.73 \\
\hline \multicolumn{5}{|l|}{ Rodents } \\
\hline Brush-tailed porcupine Atherurus africanus & $\mathrm{LC}$ & Herbivore & Medium & 0.81 \\
\hline Giant pouched rat Cricetomys emini & $\mathrm{LC}$ & Omnivore & Medium & 0.81 \\
\hline African giant squirrel Protoxerus stangeri & $\mathrm{LC}$ & Herbivore & Small & 0.65 \\
\hline Fire-footed rope squirrel Funisciurus pyrropus & LC & Herbivore & Small & 0.58 \\
\hline Lady Burton's rope squirrel Funisciurus isabella & $\mathrm{LC}$ & Herbivore & Small & 0.35 \\
\hline
\end{tabular}

${ }^{1}$ LC, Least Concern; NT, Near Threatened; EN, Endangered; CR, Critically Endangered.

${ }^{2}$ Small, $<1 \mathrm{~kg}$; medium 1-25 kg; large $>25 \mathrm{~kg}$.

\section{Occupancy analysis}

Occupancy models could be fitted for 18 mammals. For these species, estimated occupancy ranged from $0.92 \pm$ SE 0.07 for blue duiker, to $0.35 \pm \mathrm{SE} 0.10$ for Lady Burton's rope squirrel Funisciurus Isabella (Table 2). Detection probability ranged from $0.46 \pm \mathrm{SE} 0.05$ for Lady Burton's rope squirrel, to $0.02 \pm$ SE 0.01 for yellow-backed duiker. The occupancy of all species of conservation concern for which occupancy analysis was possible was $>0.5$, but their detection probabilities were low $(\leq 0.15)$.

Bates' pygmy antelope Neotragus batesi and agile mangabey were the only species for which the null model (no covariates included) was the top-ranked model. Proximity to the river was the most common predictor of occupancy. Tree cover was negatively correlated with occupancy for chimpanzees, implying that chimpanzee occupancy increased in cropland. Proximity to the road did not have a negative influence on occupancy for any species, and had a positive influence for Peter's duiker. Proximity to the Reserve had a positive effect on the occupancy of three rodents (brush-tailed porcupine, giant squirrel Protoxerus stangeri and giant pouched rat Cricetomys emini) and a negative effect on the occupancy of bay duiker and firefooted rope squirrel Funisciurus pyrropus. For model selection details, model outputs and (Q)AICcWt information, see Supplementary Tables 3-5.

\section{Discussion}

The Dja region in Cameroon is important for mammals (Bruce et al., 2018a), but there is increasing human activity and pressure on wildlife, and more surveys are needed to evaluate the status of mammal populations. We conducted a camera-trap survey in a previously unsurveyed community forest and adjacent habitat surrounding a village to the south-east of the Dja Biosphere Reserve and identified 24 mammal species, including six with an IUCN Red List status of Near Threatened or threatened: two medium-sized and large duikers (bay and yellow-backed), putty-nosed monkey, tree pangolin, chimpanzee and western lowland gorilla. Four of these species of conservation concern used 
TABLE 2 Estimates of occupancy $(\psi)$ and detection probability $(p)$ for mammals identified by camera trapping in the community forestand adjacent habitat surrounding the study village, from the top-ranked model or the average of the top ranked models. The effect of each covariate on $\psi$ and $p$ is shown by symbols if it occurs in the top ranked model or models: + is a positive effect and - is a negative effect. Parentheses indicate significant effects $(\mathrm{P}<0.05)$.

\begin{tabular}{|c|c|c|c|c|c|c|c|c|c|}
\hline \multirow[b]{2}{*}{ Species } & \multicolumn{5}{|l|}{ Occupancy } & \multicolumn{4}{|c|}{ Detection probability } \\
\hline & $\psi \pm \mathrm{SE}$ & $\begin{array}{l}\text { Proximity } \\
\text { to river }\end{array}$ & $\begin{array}{l}\text { Proximity } \\
\text { to road }\end{array}$ & $\begin{array}{l}\text { Proximity } \\
\text { to Reserve }\end{array}$ & Tree cover & $p \pm \mathrm{SE}$ & Slope & $\begin{array}{l}\text { Proximity } \\
\text { to road }\end{array}$ & $\begin{array}{l}\text { Proximity } \\
\text { to Reserve }\end{array}$ \\
\hline \multicolumn{10}{|l|}{ Carnivores } \\
\hline Servaline genet & $0.60 \pm 0.18$ & & & & & $0.05 \pm 0.02$ & & & $(-)$ \\
\hline Herpestidae spp. & $0.72 \pm 0.23$ & + & & & & $0.07 \pm 0.03$ & & & \\
\hline \multicolumn{10}{|l|}{ Pangolins } \\
\hline Tree pangolin & $0.52 \pm 0.61$ & + & & & & $0.03 \pm 0.02$ & & & \\
\hline \multicolumn{10}{|l|}{ Ungulates } \\
\hline Blue duiker & $0.92 \pm 0.07$ & - & & & & $0.40 \pm 0.03$ & & & $(+)$ \\
\hline Bay duiker & $0.60 \pm 0.12$ & & & - & & $0.15 \pm 0.03$ & & $(+)$ & \\
\hline Yellow-backed duiker & $0.66 \pm 0.28$ & & & & & $0.02 \pm 0.01$ & & & $(+)$ \\
\hline Peter's duiker & $0.84 \pm 0.10$ & - & + & & & $0.19 \pm 0.02$ & & & \\
\hline Bates' pygmy antelope & $0.46 \pm 0.42$ & & & & & $0.03 \pm 0.03$ & & & \\
\hline Red river hog & $0.58 \pm 0.14$ & & & & & $0.10 \pm 0.03$ & & - & \\
\hline \multicolumn{10}{|l|}{ Primates } \\
\hline Chimpanzee & $0.72 \pm 0.40$ & + & & & - & $0.04 \pm 0.02$ & & & \\
\hline Agile mangabey & $0.77 \pm 0.09$ & & & & & $0.26 \pm 0.03$ & & & \\
\hline \multicolumn{10}{|l|}{ Rodents } \\
\hline Brush-tailed porcupine & $0.88 \pm 0.08$ & + & & + & & $0.35 \pm 0.03$ & & $(+)$ & $(-)$ \\
\hline Giant pouched rat & $0.85 \pm 0.08$ & & & + & & $0.41 \pm 0.03$ & + & $(+)$ & \\
\hline African giant squirrel & $0.71 \pm 0.10$ & & + & + & & $0.23 \pm 0.03$ & $(+)$ & + & \\
\hline Fire-footed rope squirrel & $0.66 \pm 0.11$ & & + & - & & $0.16 \pm 0.03$ & + & & \\
\hline Lady Burton's rope squirrel & $0.35 \pm 0.10$ & + & & & & $0.46 \pm 0.05$ & & & - \\
\hline
\end{tabular}

$>50 \%$ of the study area, albeit with low detection probability $(\leq 0.15)$, suggesting they are relatively widespread, despite the presence of a human settlement, road and persistent hunting. Our results highlight the conservation value of the community forest and support previous findings that the Dja Biosphere Reserve landscape, including the core and buffer zone, remains important for Central African mammals (Bruce et al., 2018c; Lhoest et al., 2020).

The species richness in our study area is less than estimates from within the Dja Biosphere Reserve of 26 (Northern Sector) and 31 (Southern Sector) medium-sized and large species (Bruce et al., 2018a), consistent with the assumption that human activity within and around the village and community forest is greater than inside the Reserve. In cases of severe overexploitation, with hunters optimizing their catch value (Alvard, 1998), only highly productive, generalist species remain, such as giant pouched rats and blue duikers (Abernethy et al., 2013; Rosin \& Poulsen, 2016). However, some medium-sized and large species were detected in the community forest, suggesting it is not a completely empty forest sensu Redford (1992). However, we did not detect most of the large species, including forest elephant, bongo Tragelaphus eurycerus, large felids and the giant ground pangolin, and the community was dominated by smaller species. Although we do not have conclusive evidence that the larger species are absent, our findings are similar to other studies that have documented a reduced mammal species richness and dominance of smaller species around villages and community forests in Central Africa, characteristic of local wildlife depletion (Beirne et al., 2019; Lhoest et al., 2020).

The numbers of great apes usually decline rapidly under intensive hunting (Walsh et al., 2003); the presence of both the gorilla and chimpanzee is therefore a positive sign for conservation within the community forest. Populations of both have declined in the Dja Biosphere Reserve (Bruce et al., 2018c; UNESCO, 2019), and neither were identified in the community forests surveyed by Lhoest et al. (2020). However, the low number of records of gorillas suggests they may be rare or present at low density. Chimpanzees appear to be well distributed throughout most of the study area, although the occupancy estimate is imprecise, and we found no relationship between occupancy and proximity to the logging road, suggesting some tolerance of disturbance (Vanthomme et al., 2013). We also found a slightly positive correlation between chimpanzee occupancy and cropland, possibly reflecting an attraction to crops in the study area (Arlet \& Molleman, 2010).

Medium-sized duikers responded positively to human activity, with greater occupancy near the road (Peter's 
duiker), closer to the village and in areas with greater human population density (bay duiker). This could result from an increase in favourable resources. Clark et al. (2009) and Vanthomme et al. (2013) similarly found a positive correlation between these duikers and disturbance from roads, logging and settlements. Peter's duikers may be able to withstand hunting as a result of a higher maximum sustainable yield (van Vliet \& Nasi, 2008), but bay duikers are less resilient (van Vliet et al., 2007) and could be more susceptible to unsustainable hunting in the community forest.

The most commonly hunted bushmeat species (blue duiker, brush-tailed porcupine and giant pouched rat; Fa et al., 2006) had high estimates of occupancy and detection probability, indicating generally high abundance because, all else being equal, detection probability increases with abundance (MacKenzie et al., 2006). Their high detection probability could also be linked to our survey protocol, as these species tend to use the trails along which cameras were placed, and similarly some species that were not detected may be less likely to use these trails or may require more specific camera placements (e.g. Bruce et al., 2018b). Nevertheless, occupancy increased towards the Reserve for brush-tailed porcupines and giant pouched rats, suggesting that hunting of these species could be depleting populations close to the village. Blue duikers appear to be unaffected by this, as their distribution does not show the same pattern, potentially reflecting their ability to cope with hunting (van Vliet \& Nasi, 2008; Ehlers Smith et al., 2018).

Although we cannot tell from one survey what role the community forest has played in shaping the mammal community, its presence may have increased awareness about the need for hunting sustainably (Ngang, 2015). However, several other factors could also explain why our study area remains important for mammals. The location of the village close to the protected area allows movement of individuals from the Reserve to the community forest (Dupain et al., 2004). Additionally, the village is remote and, before the logging road was built, it was very isolated, limiting access to bushmeat markets and perhaps reducing the incentive to hunt for income, until recently. The improved market access provided by the road may have led to increased hunting offtake (Ziegler et al., 2016) and increased threat to the species we detected. However, as there are no previous survey data, it is vital that further surveys are conducted.

Many of the mammal species found in the Dja region are threatened or have declining populations (IUCN, 2021) and would benefit from systematic monitoring. Half of the medium-sized and large species we did not detect have an IUCN Red List status of Near Threatened or threatened, and although we detected Critically Endangered gorillas, we did not obtain a sufficient number of photographs to model their occupancy. For the threatened species for which we could model occupancy, our occupancy estimates had large standard errors as a result of low detection probabilities. Our findings highlight the difficulty of monitoring threatened mammals, especially in forest habitats (Wilcox et al., 2019). However, only with continued monitoring efforts over time and measurements of offtake will it be possible to identify species population trends and estimate hunting sustainability (Ntube et al., 2002; MilnerGulland \& Rowcliffe, 2007), which are essential for species conservation and sustainable forest management within the community forest.

Acknowledgements We thank Thomas Bruce for his help with species identifications, The European Space Agency Climate Change Initiative Land Cover project for data, and the anonymous reviewers for their feedback and suggestions. This research was carried out as part of the corresponding author's master's degree at Imperial College London and the open access article processing charge was covered by the Imperial Open Access Fund. This research received no other specific grant from any funding agency, or commercial or not-for-profit sectors.

Author contributions Survey design: SB; fieldwork: SB, FK, CTKT; data analysis, writing: SJT; guidance, editing: SB, JMR.

\section{Conflicts of interest None.}

Ethical standards This research abided by the Oryx guidelines on ethical standards. Free informed consent was obtained from the village chief and inhabitants of the study village to conduct this research, and they were aware they could withdraw their consent at any time. Any images of people obtained by the camera traps were deleted. The village name is not presented to ensure anonymity. This research was approved by Oxford University's Central University Research Ethics Committee (R45771/RE001).

\section{References}

Abernethy, K., Coad, L., Taylor, G., Lee, M. \& Maisels, F. (2013) Extent and ecological consequences of hunting in Central African rainforests in the twenty-first century. Philosophical Transactions of the Royal Society B: Biological Sciences, 368, 20120303.

Ahumada, J., Silva, C., Gajapersad, K., Hallam, C., Hurtado, J., Martin, E. et al. (2011) Community structure and diversity of tropical forest mammals: data from a global camera trap network. Philosophical Transactions of the Royal Society B: Biological Sciences, 366, 2703-2711.

Alemagi, D. (2011) Sustainable development in Cameroon's forestry sector: progress, challenges, and strategies for improvement. African Journal of Environmental Science and Technology, 5, 65-72.

Alvard, M. (1998) Evolutionary ecology and resource conservation. Evolutionary Anthropology, 7, 62-74.

Amin, R., Andanje, S., Ogwonka, B., Ali, A., Bowkett, A., Omar, M. \& WACHER, T. (2015) The northern coastal forests of Kenya are nationally and globally important for the conservation of Aders' duiker Cephalophus adersi and other antelope species.

Biodiversity and Conservation, 24, 641-658.

Arlet, M. \& Molleman, F. (2010) Farmers' perceptions of the impact of wildlife on small-scale cacao cultivation at the northern periphery of Dja Faunal Reserve, Cameroon. African Primates, 7, 27-34.

Beirne, C., Meier, A., Mbele, A., Menie, G., Froese, G., Okouyi, J. \& Poulsen, J. (2019) Participatory monitoring reveals 
village-centered gradients of mammalian defaunation in Central Africa. Biological Conservation, 233, 228-238.

Bruce, T., Amin, R., Wacher, T., Fankem, O., Ndjassi, C., Bata, M. et al. (2018a) Using camera trap data to characterise terrestrial larger-bodied mammal communities in different management sectors of the Dja Faunal Reserve, Cameroon. African Journal of Ecology, 56, 759-776.

Bruce, T., Kamta, R., Mbobda, R., Kanto, S., Dibrilla, D., Moses, I. et al. (2018b) Locating giant ground pangolins (Smutsia gigantea) using camera traps on burrows in the Dja Biosphere Reserve, Cameroon. Tropical Conservation Science, 11, 1-5.

Bruce, T., Ndjassi, C., Fowler, A., Ndimbe, M., Fankem, O., Mrodbda, R. et al. (2018c) Faunal Inventory of the Dja Faunal Reserve, Cameroon - 2018. Ministry of Forests and Wildlife (MINFOF), Zoological Society of London - Cameroon Country Programme, African Wildlife Foundation, Yaoundé, Cameroon.

Burnham, K. \& Anderson, D. (2002) Model Selection and Multimodel Inference. 2nd edition. Springer, Berlin, Germany.

Butchart, S., Walpole, M., Collen, B., van Strien, A., Scharlemann, J., Almond, R. et al. (2010) Global biodiversity: indicators of recent declines. Science, 328, 1164-1168.

Center for International Earth Science Information Network (CIESIN) Columbia University (2018) Gridded Population of the World, Version $4(G P W v 4)$ : Administrative Unit Center Points with Population Estimates, Revision 11. NASA Socioeconomic Data and Applications Center (SEDAC), Palisades, USA. doi.org/10.7927/H4BC3WMT [accessed 28 June 2020].

Clark, C., Poulsen, J., Malonga, R. \& Elkan, P. Jr (2009) Logging concessions can extend the conservation estate for Central African tropical forests. Conservation Biology, 23, 12811293.

Cowlishaw, G., Mendelson, S. \& Rowcliffe, M. (2005) Evidence for post-depletion sustainability in a mature bushmeat market. Journal of Applied Ecology, 42, 460-468.

Da Silva, M., Paviolo, A., Tambosi, L. \& Pardini, R. (2018) Effectiveness of Protected Areas for biodiversity conservation: mammal occupancy patterns in the Iguaçu National Park, Brazil. Journal for Nature Conservation, 41, 51-62.

Dupain, J., Guislain, P., Nguenang, G., De Vleeschouwer, K. \& VAn Elsacker, L. (2004) High chimpanzee and gorilla densities in a non-protected area on the northern periphery of the Dja Faunal Reserve, Cameroon. Oryx, 38, 209-216.

EgBe, S. (2001) The law, communities and wildlife management in Cameroon. Rural Development Forestry Network, 25e, 1-12.

Ehlers Smith, Y., Ehlers Smith, D., Ramesh, T. \& Downs, C. (2018) Forest habitats in a mixed urban-agriculture mosaic landscape: patterns of mammal occupancy. Landscape Ecology, $33,59-76$.

ESA CCI Land Cover Team (2017) S2 Prototype LC 2om Map of Africa 2016. 2016africalandcover2om.esrin.esa.int [accessed July 2020].

Ezzine-de-Blas, D., Pérez, M., Sayer, J., Lescuyer, J., Nasi, R. \& Karsenty, A. (2009) External influences on and conditions for community logging management in Cameroon. World Development, 37, 445-456.

Fa, J., Currie, D. \& Meeuwig, J. (2003) Bushmeat and food security in the Congo Basin: linkages between wildlife and people's future. Environmental Conservation, 30, 71-78.

Fa, J., Seymour, S., Dupain, J., Amin, R., Albrechtsen, L. \& Macdonald, D. (2006) Getting to grips with the magnitude of exploitation: bushmeat in the Cross-Sanaga rivers region, Nigeria and Cameroon. Biological Conservation, 129, 497-510.

Fa, J., Wright, J., Funk, S., Márquez, A., Olivero, J., Farfán, M. et al. (2019) Mapping the availability of bushmeat for consumption in Central African cities. Environmental Research Letters, 14, 94002.
Fiske, I. \& Chandler, R. (2011) Unmarked: an $R$ package for fitting hierarchical models of wildlife occurrence and abundance. Journal of Statistical Software, 43, 1-23.

Gruber, J., Mbatu, R., Johns, R. \& Dixon, B. (2018) Measuring conservation success beyond the traditional biological criteria: the case of conservation projects in Costa Rica, Mekong Valley, and Cameroon. Natural Resources Forum, 42, 19-31.

Hoffmann, M., Belant, J., Chanson, J., Cox, N., Lamoreux, J., Rodrigues, A. et al. (2011) The changing fates of the world's mammals. Philosophical Transactions of the Royal Society B, 366, 2598-2610.

Ingram, D., Coad, L., Abernethy, K., Maisels, F., Stokes, E., Вово, K. et al. (2018) Assessing Africa-wide pangolin exploitation by scaling local data. Conservation Letters, 11, 1-9.

IUCN (2021) The IUCN Red List of Threatened Species. Version 2021-2. iucnredlist.org [accessed 3 November 2021].

Kingdon, J. (2015) The Kingdon Field Guide to African Mammals. and edition. Bloomsbury, London, UK.

Koerner, S., Poulsen, J., Blanchard, E., Okouyi, J. \& Clark, C. (2017) Vertebrate community composition and diversity declines along a defaunation gradient radiating from rural villages in Gabon. Journal of Applied Ecology, 54, 805-814.

LAGARDE, J. (2004) Impact of Forest Logging in the Dja Biosphere Reserve, Cameroon. Ministry of Environment and Forestry/PSRF, Yaoundé, Cameroon.

Laporte, N., Stabach, J., Grosch, R., Lin, T. \& Goetz, S. (2007) Expansion of industrial logging in Central Africa. Science, 316, 1451.

Laurance, W., Croes, B., Tchignoumba, L., Lahm, S., Alonso, A., LEE, M. et al. (2006) Impacts of roads and hunting on Central African rainforest mammals. Conservation Biology, 20, 1251-1261.

LesCuyer, G. (2013) Sustainable forest management at the local scale: a comparative analysis of community forests and domestic forests in Cameroon. Small-Scale Forestry, 12, 51-66.

Lhoest, S., Fonteyn, D., Daînou, K., Delbeke, L., Doucet, J.-L., Dufrêne, M. et al. (2020) Conservation value of tropical forests: distance to human settlements matters more than management in Central Africa. Biological Conservation, 241, 108351.

MacKenzie, D. \& Bailey, L. (2004) Assessing the fit of site-occupancy models. Journal of Agricultural, Biological, and Environmental Statistics, 9, 300-318.

MacKenzie, D., Nichols, J., Lachman, G., Droege, S., Royle, J. \& LANGTIMm, C. (2002) Estimating site occupancy rates when detection probabilities are less than one. Ecology, 83, 2248-2255.

MacKenzie, D., Nichols, J., Royle, J., Pollock, K., Bailey, L. \& Hines, J. (2006) Occupancy Estimation and Modeling: Inferring Patterns and Dynamics of Species Occurrence. Elsevier, Cambridge, USA.

Mazerolle, M. (2017) AICcmodavg v2.1-1. rdocumentation.org/ packages/AICcmodavg/versions/2.1-1 [accessed 24 November 2019].

Milner-Gulland, E. \& Rowcliffe, J. (2007) Conservation and Sustainable Use. A Handbook of Techniques. Oxford University Press, New York, USA.

Murphy, A., Goodman, S., Farris, Z., Karpanty, S., Andrianjakarivelo, V. \& Kelly, M. (2017) Landscape trends in small mammal occupancy in the Makira-Masoala protected areas, northeastern Madagascar. Journal of Mammalogy, 98, 272-282.

Nasi, R., Taber, A. \& van Vliet, N. (2011) Empty forests, empty stomachs? Bushmeat and livelihoods in the Congo and Amazon Basins. International Forestry Review, 13, 355-368.

NGANG, D. (2015) Contribution of community based natural resource management to livelihoods, conservation and governance in Cameroon. A comparative assessment of three community forests in Fako Devision. Thesis, Pan African Institute for Development West Africa, Buea, Cameroon. 
Ntube E., Ondoa, T., Mba, A., Fawoh, J., Mojoko, S., Tekwe, C. \& Acworth, J. (2002) Forest Management Plan for the Mokoko River Forest Reserve. Mt Cameroon Project/MINEF, Buea, Cameroon.

Oksanen, J., Blanchet, F., Friendly, M., Kindt, R., Legendre, P., McGlinn, D. et al. (2019) vegan: Community Ecology Package. $R$ package version 2.5-6. CRAN.R-project.org/package=vegan [accessed 14 July 2020].

Oyono, P., Ribot, J. \& LaRson, A. (2006) Environmental Governance in Africa: Green and Black Gold in Rural Cameroon: Natural Resources for Local Governance, Justice and Sustainability. World Resources Institute, Institutions and Governance Program, Washington, DC, USA.

Peres, C. (200o) Effects of subsistence hunting on vertebrate community structure in Amazonian forests. Conservation Biology, 14, 240-253.

Potapov, P., Turubanova, S., Hansen, M., Adusei, B., Broich, M., Altstatt, A. et al. (2012) Quantifying forest cover loss in Democratic Republic of the Congo, 2000-2010, with Landsat ETM+ data. Remote Sensing of Environment, 122, 106-116.

QGIS Development Team (2018) QGIS Geographic Information System. Open Source Geospatial Foundation Project. qgis.osgeo.org [accessed 24 Nov 2019].

Redford, K. (1992) The empty forest. BioScience, 42, 412-422.

Reilly, M., Tobler, M., Sonderegger, D. \& Beier, P. (2017) Spatial and temporal response of wildlife to recreational activities in the San Francisco Bay ecoregion. Biological Conservation, 207, 117-126.

Rich, L., Davis, C., Farris, Z., Miller, D., Tucker, J., Hamel, S. et al. (2017) Assessing global patterns in mammalian carnivore occupancy and richness by integrating local camera trap surveys. Global Ecology and Biogeography, 26, 918-929.

Robinson, J. \& Bennett, E. (2004) Having your wildlife and eating it too: an analysis of hunting sustainability across tropical ecosystems. Animal Conservation, 7, 397-408.

Rosa, I., Smith, M., Wearn, O., Purves, D. \& Ewers, R. (2016) The environmental legacy of modern tropical deforestation. Current Biology, 26, 2161-2166.

Rosin, C. \& Poulsen, J. (2016) Hunting-induced defaunation drives increased seed predation and decreased seedling establishment of commercially important tree species in an Afrotropical forest. Forest Ecology and Management, 382, 206-213.

R Core Team (2019) R: A Language and Environment for Statistical Computing. R Foundation for Statistical Computing, Vienna, Austria.
Santos, P., Chiarello, A., Ribeiro, M., Ribeiro, J. \& Paglia, A. (2016) Local and landscape influences on the habitat occupancy of the endangered maned sloth Bradypus torquatus within fragmented landscapes. Mammalian Biology, 81, 447-454.

Tobler, M., Carrillo-Percastegui, S., Leite Pitman, R., Mares, R. \& Powell, G. (2008) An evaluation of camera traps for inventorying large- and medium-sized terrestrial rainforest mammals. Animal Conservation, 11, 169-178.

UNESCO (2019) Analysis and Conclusion by World Heritage Centre and the Advisory Bodies in 2019. whc.unesco.org/en/soc/3918 [accessed 15 July 2020].

United Nations (2019) World Population Prospects 2019: Highlights. United Nations, Department of Economic and Social Affairs, Population Division, New York, USA.

VAN Vliet, N. \& NASI, R. (2008) Hunting for livelihood in northeast Gabon: patterns, evolution, and sustainability. Ecology and Society, 13,33 .

van Vliet, N., Nasi, R., Emmons, L., Feer, F., Mbazza, P. \& Bourgarel, M. (2007) Evidence for the local depletion of bay duiker (Cephalophus dorsalis), within the Ipassa Man and Biosphere Reserve, northeast Gabon. African Journal of Ecology, 45, 440-443.

Vanthomme, H., Kolowski, J., Korte, L. \& Alonso, A. (2013) Distribution of a community of mammals in relation to roads and other human disturbances in Gabon, Central Africa. Conservation Biology, 27, 281-291.

Walsh, P., Abernethy, K., Bermejo, M., Beyers, R., De Wachter, P., Aкоu, M. et al. (2003) Catastrophic ape decline in western equatorial Africa. Nature, 422, 611-614.

WAnG, B., Sork, V., LeONG, M. \& SMith, T. (2007) Hunting of mammals reduces seed removal and dispersal of the afrotropical tree Antrocaryon klaineanum (Anacaridaceae). Biotropica, 39, 340-347.

Wasser, S., Brown, L., Mailand, C., Mondol, S., Clark, W., Laurie, C. \& Weir, B. (2015) Genetic assignment of large seizures of elephant ivory reveals Africa's major poaching hotspots. Science, 349, 84-87.

Wilcox, D., Nash, H., Trageser, S., Kim, H., Hywood, L., Connelly, E. et al. (2019) Evaluating methods for detecting and monitoring pangolin (Pholidata: Manidae) populations. Global Ecology and Conservation, 17, eoo539.

Ziegler, S., Fa, J., Wohlfart, C., Streit, B., Jacob, S. \& Wegmann, M. (2016) Mapping bushmeat hunting pressure in Central Africa. Biotropica, 48, 405-412. 